\title{
Activating the socialist past for a nativist future: Far-right intellectuals and the prefigurative power of multidirectional nostalgia in Dresden
}

This is a preliminary version of an article whose final and definite form was published online in Social Movement Studies (2020) (C) Informa UK Limited, trading as Taylor \& Francis Group.

Julian Göpffarth

European Institute, London School of Economics and Political Science

Address: 30-32 Dresden Road, N19 3BD London

Email: j.j.gopffarth@1se.ac.uk

Phone: 07743540890

Twitter: @ JGopffarth

LinkedIn: Julian Göpffarth

Website: http://www.lse.ac.uk/european-institute/people/research-

students/g\%C3\%B6pffarth-julian

ORCiD ID: https://orcid.org/0000-0002-1128-4710 


\begin{abstract}
:
A widespread view on the success of populist far-right parties is that they mobilise economically left-behind voters via a backward-looking, nostalgic and thus illegitimate agenda. Yet, recent research has shown that it is often wealthy areas that vote for the German populist far-right AfD. Drawing on nationalism, memory-studies and social-movement literature, this article examines how nostalgia drives the activism of well-off local intellectual far-right groups. Based on ethnographic data gathered in Dresden, I argue that far-right intellectual activism in East Germany is facilitated by the convergence of two distinct but related forms of nostalgia. First, a positive nostalgia for a guilt-free past. Second, a negative nostalgia characterized not by a celebration of socialism, but the resistance to it. As multidirectional nostalgia this convergence makes the far right's political memory resonate with local individual and social memories providing the cultural opportunity structure for electoral success. Infused with a forward-looking 'anxious hope', it prefigures an alternative far-right future.
\end{abstract}

Keywords: Germany, Far Right, AfD, Nostalgia, Memory, Prefigurative Politics

\title{
Introduction
}

Support for populist far-right parties is often seen as driven by an electorate that is economically left-behind (Berezin, 2009; Betz, 1994; Goodwin \& Milazzo, 2005), and resistant to immigration, multiculturalism (Scheepers et al., 2004; Koopmans, 2016) or the EU (Scheepers et al., 2013; Lubbers, 2008). This view is generally coupled with the assertion that supporters of far-right populism fall victim to an irrational nostalgia for an idealized past (Betz \& Johnson, 2016; Steenvoorden \& Harteveld, 2018). Yet, recent research in Germany shows that wealthy areas vote for the populist far-right Alternative für Deutschland (AfD) or support the populist far-right movement PEGIDA (Hansen \& Olsen, 2019; Vorländer et al., 2015). Furthermore, culturalist racism and nativism are not restricted to the 'far right' but reach into the mainstream (Decker \& Brähler, 2018).

I therefore propose to see nostalgia as a tool for political mobilisation, not of the fearful left-behind, but of an educated bourgeoisie engaged in a 
hopeful activism for a nativist future in a context where the ethnic framing of German identity has been delegitimised (Jones \& Smith, 2001; Shulman, 2002). I define the far right as a social movement consisting of 'multiple arenas of contestation' beyond the party sector (Castelli Gattinara \& Pirro, 2018; Veugelers \& Menard, 2018) and conceptualise intellectual circles in Dresden as far-right grassroots groups that share a common nativist platform (Mudde 2007, p. 19) for which they aim to mobilise broader support (Klandermans \& Mayer, 2005; Virchow, 2017; Göpffarth, 2020). In these circles, nostalgia is not simply a passive longing for a lost past but a political means to 'reconfigure the future through reference to the reinvented national past' (Kenny, 2017, p. 15). It provides an emotional basis for the activation of individual, social and political memories (Assmann, 2006b) from the socialist past to politicize intellectuals and their attentive audiences and to mobilise them through the prefiguration of an alternative German collective memory and far-right future. At the core here is an 'anxious hope' (Gordon, 2018) for a future similar to the nostalgic past and different from imagined dystopias.

Drawing on six months of ethnographic fieldwork, I argue that this process of politicization relies on the merging of two forms of nostalgia that refer to different pasts and challenge the German memory consensus. The first is a positive nostalgia for a guilt-free past that has a long tradition in the West German Federal Republic (FRG) but was equally ingrained in the selfunderstanding of the East German Democratic Republic (GDR). The second is a negative nostalgia characterized not by a celebration of the GDR, but of the resistance to it. Together they form a multidirectional nostalgia 'crossreferencing' and capturing 'simultaneously the individual, embodied, and lived side and the collective, social, and constructed side of our relations to the past' (Rothberg, 2009, pp. 3-4). It goes beyond a simple glorification of the past responding 'to increased anxiety' (De Vries \& Hoffmann, 2018, p. 3) or an apolitical appropriation of everyday past, as in Ostalgie (Bach, 2017). Rather, its multidirectional character helps to make a far-right political memory resonate with a local context (Snow \& Benford, 1988; Bonikowski, 2016, pp. 429-31). Through its productive dimension, it represents a hopeful imagining of an alternative future and underpins a prefigurative politics. 
Assessing the activating power of multidirectional nostalgia at the micropolitical level in Dresden not only sheds light on how the politics of nostalgia play out in social movements. It equally shows how nostalgic memories inform far-right activism for an alternative future. The findings question the predominant use of prefigurative politics and notions of 'hope' with regard to progressive movements (Blee, 2007) and show its presence in a far-right activism (Decker, 2015, p. 16). Section one discusses the phenomenon of nostalgia, its role in far right and prefigurative politics before explaining the data, case selection and methodology. The following sections review the different dynamics of memory cultures in the GDR, the FRG and the forms of nostalgia developing in reaction to the emergent post-reunification memory regime. The final section shows how these dynamics inform intellectual attempts to make far-right frames resonate with the local context (Blee, 2002; Bonikowski, 2017).

\section{The Far Right, Nostalgia and Prefigurative Politics}

Nostalgia has only recently been discussed in the political science literature (Duyvendak, 2011; Kenny, 2017; De Vries \& Hoffmann, 2018). Following a longer tradition, nationalism literature generally conceptualises nostalgia as a mythic vision of the nation's golden past (Coakley, 2004; Smith, 1996). Similarly, AfD and PEGIDA are often framed as driven by socio-economic fears yearning for a 'golden age of autarky' and imagining a reactionary utopia (Druxes, 2016b, p. 18). Here, nostalgia is linked to a yearning for socioeconomic stability in the GDR, 'together with the Honecker regime's policy of cultural regionalism' (Druxes, 2016b, p. 19) 'appropriating' revolutionary and democratic discourses of the anti-GDR movements in the 1980s (Simpson, 2016, p. 38).

Yet, this mono-directional understanding of nostalgia underplays local individual and social memories' complex entanglement with activism shaping the present. Memory studies literature provides a more nuanced view conceptualising nostalgia as an action-oriented form of remembrance that is central to individuals' and groups' readings of the present and imagining of the future (Dames, 2010, p. 272; Stewart, 1988) and carries an 'agency of yearning' 
(Whitehead, 2010). Boym distinguishes between 'restorative' and 'reflective' nostalgia (Boym, 2001). While the former hopes to restore a golden past, the latter draws on the past for a critical re-evaluation and active changing of the present. I argue that in the intellectual support of the far right in Dresden, both elements are entangled. Reflective nostalgia can be restorative, and vice versa. I thus conceptualize nostalgia more broadly as an important driving force for political change. I distinguish between positive and negative nostalgia. The former celebrates a remembered past, the latter glorifies not a past condition per se but phenomena that existed despite this past condition.

An impactful political mobilisation depends on the salience of shared memories informing nostalgia (Assmann, 2006a; Olick, 2008, p. 24) and 'memory regimes' (Langenbacher, 2010a). States, movements and parties rely on 'usable pasts', i.e. representations of the past that are 'usable' for the legitimization of present political action and the founding of political authority (Hoye \& Nienass, 2014; Wüstenberg \& Art, 2008). A nostalgic reference to a collective memory is not limited to far-right or far-left populism (De Vries \& Hoffmann, 2018, p. 5). Rather, it is a 'generic thought practice which acquires complex meanings in relation to the discursive contexts and patterns where it is employed' (Kenny, 2017, p. 3). As part of a political discourse, nostalgia can challenge a dominant 'usable past' by propagating subaltern collective memories. Through this political dimension nostalgia does not only collapse the distinction between past and present. Directed to an alternative future, it also bears a prefigurative quality. The concept of prefigurative politics (Boggs, 1977) has generally been used with reference to New Left and alterglobalization movements (Breines, 1989; Epstein, 1991) and describes a political practice aimed at the removal of the "temporal distinction between the struggle in the present and a goal in the future' (Maeckelbergh, 2011, p. 4). Prefigurative movements create their desired future in their present social relationships (Sitrin, 2006, p. 4). Situated in the context of prefigurative politics, nostalgia in Dresden far-right activism goes beyond idealizing the past. It informs an activism aimed at a far-right future providing activists with a 'generative temporal framing' and giving meaning to their activism (Gordon, 2018, p. 523). 


\section{Case, Data and Methodology}

Most studies of the far right are obtained at a distance (Toscano, 2019) overlooking the immediate local context of political mobilisation (Koopmans \& Braun, 2014). An interpretative, ethnographic approach forefronts 'individual activists' and sees 'members of such organisations "as individuals with real lives"” (Ezekiel, 1995, p. xxxv). It allows an understanding of how activists 'produce knowledge (...) in social action' (Choudry, 2015, p. 8) and which meaning they give to their activism (Pilkington, 2016, p. 10; Blee \& Creasap, 2010). It allows us to explore the complex ways far-right arguments resonate with an educated bourgeoisie. I present a sample of ethnographic data collected in Dresden between January and July 2018 in over 40 in-depth, formal semistructured and informal unstructured interviews, and participant observation in about twenty events and informal gatherings in Dresden's intellectual far-right milieu.

'Intellectual' is the term used by my informants to describe this article's protagonists and the events they engage in. I propose to take this seriously as it points to the role these individuals take up and are attributed. As populist phenomena AfD and PEGIDA are mainly seen as anti- (Druxes 2016a, p. 2) or pseudo-intellectual (Simpson, 2016, pp. 36, 41). Links of intellectual far-right circles to the populist far right are doubted (Salzborn, 2016) or assessed in a way that neglects the local context (Mense et al. 2016). PEGIDA or AfD are not intellectual phenomena. Yet, the focus the focus on their populist dimension has led to neglecting the role of intellectuals in making far-right nativism resonate with the local context (Bonikowski 2017). As producers of culture (Bourdieu 1969) intellectuals are central to this process.

In reunified Germany East German intellectuals' claims over the role of culture were marginalised (Jäger \& Villinger, 1997) and delegitimised as their entanglement with the GDR's secret police (STASI) emerged (Brockmann, 1999). They were left without agency, losing audiences, disillusioned by capitalism (Graf, 2001) and alienated by yet another 'system' that had to be mastered (Dornhof, 2001). During my fieldwork intellectuals reclaimed this agency drawing both on positive and negative nostalgia. Mediating between the mainstream and the margins (Giesen, 1998, p. 7) and culture and politics 
(Boggs, 1993, p. 10) they facilitated the resonance of far-right political memory with their attentive audiences and local socio-political experiences (Susen, 2017, pp. 11-15; Göpffarth, 2018).

Dresden is the only major German city where the AfD (19.8\%) emerged as the strongest party in the 2019 European elections (Dresden, 2019). My ethnography focusses on a bookshop owned by Susanne Dagen in Dresden's suburb Loschwitz. Since the so-called refugee crisis, the bookshop has developed into an intellectual meeting place linking local networks to a nationally active far right. The bookshop and its intellectual circles formed the 'core group' (Hochschild, 2016, p. 16) of my research. Its members are academics, students, writers, publishers, artists, city and state employees and local business owners. As representatives of local elites they are the 'right type' of activists (Art, 2011, p. 33) providing important 'resources of legitimation and validation' (Baumann, 2007, p. 56; Hollands \& Vail, 2012, p. 29-30). All interviewees actively or passively resisted the GDR regime and are now involved in far-right activism close to PEGIDA and AfD.

For this article I focus on two interviews and one participant observation exemplifying three different types of intellectuals: producing, mediating and consuming intellectuals. Each type represents a different level of intellectual creation and popularization (Geiger, 1949) of an alternative memory culture. Producing intellectuals are active regionally and nationally. Due to publications and events they hold they are known to a larger national public. Mediating intellectuals are mostly locally or regionally known. They do not produce own publications but bring producing intellectuals in contact with local attentive audiences or conceive events and activism in which the producing intellectuals or their ideas play a central role. Finally, consuming intellectuals neither produce content nor do they play a central organising role. Rather, they form the attentive audiences of producing and mediating intellectuals that attend their events and participate in post-event discussions and networking.

The data represents each type to show how the memory of GDR dissidence informs political activism and support at different levels. Producing intellectual Vera Lengsfeld is part of a group of several former GDR civil right activists and public intellectuals who support AfD and PEGIDA ${ }^{1}$. Her views are 
known through her publications or book reading tours through Germany. This article does not focus on her political positions but the way her status as a former GDR-dissident and producing intellectual allows her to use public events to merge local individual and social memories with a far-right political memory. To examine this interactive dimension, I draw on a participant observation of a book reading in Dresden.

The analysis of this event will also provide the ethnographic background for interview data from two representative local mediating and consuming intellectuals, Susanne Dagen and Martin. The mediating local intellectual, bookshop owner Susanne Dagen, organizes events such as Lengsfeld's book reading. Dagen, who frames her politicization and far-right activism through individual and social GDR memories, is a prominent local figure who links local intellectual circles to Germany-wide far-right networks. Finally, the consuming intellectual, Martin, is an academic who represents Lengsfeld's and Dagen's attentive audience. He is exemplary for this audience in his lack of public activism and the way he justifies his far-right support by referring to individual and social GDR memory. Dagen's and Martin's political views are not laid out in publications. I therefore rely on data I gathered in nine interviews I conducted with them throughout my fieldwork. The interview data was coded as 'nostalgic references to the GDR past' which emerged as a central theme that was directly related to notions of national identity, immigration and political activism. The interview data and the event are exemplary of other interviews I conducted and other events I observed during my fieldwork. Finally, all three individuals used to be politically inactive, self-described centre-left or engaged in political parties they now oppose. Today they support the far-right agenda of a future guilt-free and self-assertive Germany.

\section{Post-War Germany and Collective Memory: From Trauma to 'Usable Pasts'}

Until reunification, East and West Germany's efforts to master the Nazi past and construct 'usable pasts' followed different trajectories with the same goal: to legitimize their statehood by portraying themselves as post-fascist states (Fulbrook, 1999; Wüstenberg \& Art, 2008). In the GDR, memory of non-communist Nazi victims was supressed, anti-Semitism ignored, and 
Nazi perpetrators reintegrated into society (Herf, 1997; Olsen, 2015). The socialist state built its legitimacy on the myth of communist resistance against Nazism and a nationhood defined through class, local traditions and Heimat (Palmowski, 2009; Peitsch \& Sayner, 2015). Intellectuals were central in linking socialist re-education to German national culture (Dornhoff, 2001). As most GDR citizens were socialized by these memory politics aimed at a collective guilt-free memory (Kattago, 2001, p. 82) it remains powerful to this day (Leo, 2004).

The early FRG equally lacked a critical assessment of Nazism (Frei, 1996), even if a unified state policy like that in the GDR was absent. National belonging was not constructed by referring to the past but by focusing on economic strength (Maier, 1988) and Europe (Cohen, 2010). Not until the 1960s did a generational shift and legislative and societal debates lead to critical assessment of the past. In the 1980s, this critical memory culture reached a broader social basis through citizens' initiatives (Wüstenberg, 2017, p. 3) facilitating a consensus on collective Holocaust memory (Moses, 2007; Probst, 2003) as the absolute referent 'from which notions of political belonging could be thought anew' (Hoye \& Nienass, 2014, p. 417).

This shift gained salience in the context of post-reunification Germany where drawing on nostalgia to mobilise political support remained difficult. As unfavourable cultural opportunity structures, collective memories of its totalitarian past(s) curbed the political chances for parties on the radical left and right (Art, 2018, p. 80) - a blocking effect increasingly losing its strength (Caramani \& Manucci, 2019). Following the 'memory boom' (Winter, 2000) in the 1990s and 2000s, the interest in reworking the Nazi past (Langenbacher, 2010b) decreased overall. This, however, did not lead to the emergence of a 'normal' national pride side-lining the Holocaust as some had expected (Langenbacher, 2014). Instead, Germany developed an assertive national self-understanding not despite but because of the way it faced the Nazi past (Wittlinger, 2008). The positive memory of having dealt with the past emerged as a new 'usable past'. 


\section{Reunification and Its Nostalgic Discontents}

The nostalgia driving intellectual far-right support in Dresden grows out of these memory discourses. Nostalgia is not only a form of refusal to feel at home in a political regime (Roth, 1991, pp. 15, 19) but also a memory regime. After reunification, Germany witnessed two nostalgic reactions to the hegemonizing critical memory regime: East German Ostalgie and West German far-right nostalgia.

In West Germany, reunification ended the east-west antagonism. Subsequent debates of national identity led to a wave of far-right publications that aimed to reassess the FRG's memory consensus (Olick, 2003) calling for a more 'self-confident nation' celebrating its pre-1933 past (Rohrmoser, 1990; Schwilk, 1995) and opposing a Holocaust-focused collective memory. This opposition was politically embodied by far-right parties (Heilbrunn, 1996; Müller, 1999) but it also chimed with wider parts of society (Assmann, 2013). Most recently this is politically expressed by the AfD. Founded in 2013, its initial anti-EU nationalism has increasingly become the political platform for a far-right nativism (Göpffarth, 2017). The so-called 2015 refugee crisis and the AfD's electoral success led to a second wave of far-right publications sharing the first wave's aim: to overcome a 'self-hate creating' memory culture (Ley \& Lichtmesz, 2018; Sieferle, 2017).

In East Germany, reunification led to a different form of nostalgia. East Germany's myth of anti-fascism was critically reassessed (Morina, 2011, p. 242) and its guilt-free 'usable past' brought into question (Clarke \& Wölfel, 2011, p. 3). East German anti-immigrant violence allowed a Westdominated public discourse to portray East Germany as the place where Nazism had survived unchallenged while West German anti-immigrant violence was largely neglected. Many East Germans experienced this as a double humiliation: the abrupt vanishing of GDR symbols was perceived as a devaluation that was exacerbated by the conflation of the GDR with Nazism (Glaeser, 2000). Ostalgie emerged as a renewed interest in symbols of the socialist past and 'a defence mechanism against the uncertainties caused by rapid political and economic changes' (Sierp, 2009, pp. 49-50). 
As a symbolic resistance to West-dominated politics (Bach, 2015, p. 139), it depoliticised public GDR symbols and turned them into privatized and commodified objects challenging 'nation-building agendas of the new Germany' from the margins (Berdahl, 1999, p. 193).

As a Holocaust-centred collective memory was part of the Westdominated nation-building process Ostalgie can be interpreted as a symbolic resistance nostalgically celebrating a guilt-free past. While Ostalgie represented a depoliticized nostalgia for a guilt-free past sought in everyday symbols, individual and social memory, far-right nostalgia represented a political memory. While Ostalgie was highly symbolic, far-right nostalgia lacked meaningful forms of past resistance that would not refer to the Nazi past. It remained largely limited to West Germany and failed to gain broader support (Salzborn, 2016, p. 43-45). Today we can observe a symbiosis of Ostalgie and far-right nostalgia. The pervasive symbolism of Ostalgie in East Germany, its apolitical, social and individual character and its link to a guilt-free memory provide the far right with an effective cultural opportunity structure politically activating the socialist past for a nativist future.

\section{Multidirectional Nostalgia and Far-Right Activism}

\section{Politicizing GDR-memory}

The 19th April 2018 is one of the first warm days in Dresden. Despite the good weather, the Lindengarten, a former ballroom, is full. About 70 guests, mostly men between 40 and 60, wait for Vera Lengsfeld to give a bookreading. A former GDR civil rights activist and Green Party politician, Lengsfeld is today a member of the CDU. Recently, she has become a vocal far-right intellectual and initiated the Erklärung 2018 (Declaration 2018), a petition against 'illegal mass immigration'. Calling for intellectual solidarity with street protests like PEDIGA (Lengsfeld, 2018a) it aims, as Lengsfeld says, 'to do what the support of GDR intellectuals did to resistance in 1989.' Its webpage shows a photograph of a 1989 anti-regime demonstration in 
Berlin. The petition received more than 165,000 signatures from conservative and far-right intellectuals.

Like the declaration the lecture's location symbolizes the convergence of two pasts: GDR-dissidence and guilt-free national greatness. Built in the late 19th century, the ballroom embodies the rise of the German Empire during the Gründerzeit ${ }^{2}$ (Kukula \& Helas, 2007): a 'golden age' during which a national cultural identity was formed, national selfconfidence soared, and a memory of guilt appeared unimaginable. This guilt-free past literally frames the lecture's nostalgic remembering of 1989.

The reading is part of Lengsfeld's promotional tour for her book 1989: Diary of a Peaceful Revolution (Lengsfeld, 2014) and the Declaration 2018. In the reading, she meticulously describes every day in 1989 leading up to the revolution. Lengsfeld claims that today, 'we live in a society, where the GDR has been resurrected in the shape of a chimera (...) and where you can earn a prize for civil courage when you carve a swastika into your hip and claim that it was done by right extremists' (Lengsfeld, 2014, p. 9). She argues that a fading memory of the socialist dictatorship and an emphasis on the Nazi past led to a societal climate conducive to the return of a leftist totalitarianism. Setting the scene for her far-right activism she shows how memory of anti-GDR activism is used to frame resistance to a 'left-liberal totalitarianism' - an old far-right narrative (Müller, 1999, pp. 202-203).

In the reading Lengsfeld reads out the notes on the 19th of every month in 1989 and sets the events in direct relation to the present day, 19 April 2018. Her words bring back the heated atmosphere of the GDR's last months. The audience listens carefully to the detailed accounts. Whenever Lengsfeld mentions familiar situations and known events, one sees nodding heads and hears sentences like 'that's the way it was' or 'I had totally forgotten about that'. Lengsfeld makes sure that the present context is not seen as detached from memories of GDR resistance:

'Today's situation is not far from 1989. Look at the denial of reality by the established parties. Their discourse on immigration reminds me of the 
wishful thinking of the GDR's political leadership. Reality and the mood in the country are simply neglected' (Lengsfeld 2018b).

Lengsfeld pushes the analogy further: 'Then, STASI and state were the pig system $^{3}$. Today, the pig system is the state paying the ANTIFA'. The message is clear: the resistance against the GDR regime and STASI needs to be re-established against a 'new leftist dictatorship', Merkel and ANTIFA. 'We need another revolution to stop the destruction of our beautiful country' she says. Intertwining Lengsfeld's personal account with the listeners' individual and local social memory, a new shared memory in the present is forged and pitted against a 'repressive leftist-liberal state'. Individual and collective memories are socially co-constructed and revised from a far-right perspective ${ }^{4}$. Co-constructing an alternative past, political, individual and collective memories are synchronized (equating 1989's day-to-day events to today) to drive present and future political activism.

What this future should look like can be read in the books of farright authors. Lengsfeld's lecture is chaired by Dagen, whose bookshop is represented with a bookstand. Lengsfeld's book is sold along with the farright books Finis Germania or Nationalmasochismus (Ley \& Lichtmesz, 2018; Sieferle, 2017), which call for an end to German self-hate and for a German Volk based on a 'positive, mobilizing, self-affirmative identity which is necessary for the survival and thriving of a nation' (Ley \& Lichtmesz, 2018, p. 10).

\section{Mediating between political and local memory}

Since its founding in 1992, Dagen's bookshop has developed into a respected centre for intellectuals in Dresden winning the German bookshop prize twice. Today, it brings together the local educated bourgeoisie, former GDR activists and far-right intellectuals. In the Kulturhaus adjacent to the bookshop Dagen holds events like the Lengsfeld lecture as part of the series ZeitZeuge: Ein Leben zwischen Diktatur und Demokratie (Contemporary Witness: A Life between Dictatorship and Democracy) and 70 Jahre DDR (70 Years GDR), cooperating with the Association of the Politically 
Persecuted by Communism and implying a continuation of the GDRtotalitarianism into the present. Dagen benefitted from a cooperation with Dresden's administration allowing her to advertise events on the municipal library's flyer - a proof of her local standing. The event space next to her bookshop is crowded in most of the events I attended; seats are hard to get for late arrivals. Dagen initiated the Charta 2017, an online petition against an increasing 'dictatorship of opinion' drawing open parallels to antisocialist dissidence (Charta 2017, 2017) that was signed by more than 7.800 supporters. The petition led to a widely-reported debate held in the city's central event-space between writers Uwe Tellkamp and Durs Grünbein (Reinhard 2018; Die Welt, 2018), the former supporting PEGIDA/AfD positions while the latter represented 'a rootless intellectual without connection to the people' as Dagen says.

Dagen popularizes Lengsfeld's and the far right's alternative past to show, as she says, that 'it's possible to topple a system a second time'. To do so she can rely on a local intellectual tradition. As Saxony's capital with more than 500,000 inhabitants, Dresden has always been a city with a vibrant intellectual scene. In the 1980s, Dresden's intellectual subculture was thriving and notorious for its non-conformism (Kaiser \& Petzhold, 1997, pp. 145-147). One centre of this subculture was Loschwitz (Kaiser \& Petzhold, 1997, pp. 157-163), a picturesque Dresden suburb and a 'bohemian biotope' for utopias and alternative lifestyles that formed against GDR-reality (Kaiser \& Petzhold, 1997, pp. 148-149). Here activism was not arguing for different politics but based on the premise that everything legally possible needed to be done to 'piss off the socialist state', as a former activist told me. Members of this bohemia organized events, dressing up in bourgeois costumes that symbolized all the socialist state was against, a form of activism based on gestures of non-conformity widespread in totalitarian socialist states in the 1980s (Ost, 2005). Today, Dresden's intellectual scene provides a cultural opportunity structure for intellectual far-right activism. As actors at the intersection of culture and politics intellectuals contribute to the legitimisation and sustaining (Baumann, 2007; Reed, 2005) of the far-right movement. Individuals like Lengsfeld and 
Dagen can draw on well-established East German social repertoires of protest (Lahusen \& Bleckman, 2015) and common political networks (Weisskircher \& Berntzen, 2018) that transcend the left-right divide (Dilling, 2018) and impact German national politics (Patton, 2017).

Dagen has turned Loschwitz into an intellectual centre supporting PEGIDA and AfD. Her bookshop is situated off the main street in an 18thcentury house and has an alternative flair aimed not at 'commercial profit but long-term customer relations' as Dagen says. Its interior carries the patina of an old library - 'a perfect place to step back from the hectic every day, resist the Zeitgeist and gain strength to face contemporary challenges by reading', she states. It serves as an alternative space for political discussions and informal meetings to plan projects. It prefigures a far-right future based on 'community, solidarity, the celebration of German culture and politics that focus not on economic profit in the present but the future of German culture'. Dagen functions as a local public intellectual at the intersection of national and local far-right audiences. She is in regular contact with Götz Kubitschek, founder of the far-right think tank Institut für Staatspolitik and its publishing house Antaios. Far-right authors are regular guests in the bookshop, presenting their books and networking with local intellectuals.

Dagen justifies her support for AfD and PEGIDA in her East German biography. 'We all have been through this before. Being pressured by the state, having to risk one's existence because of what one says. We have scissors in the head, back then and today' she says, alluding to selfcensorship in the 1980s. 'The difference today: it is not the state that is creating this pressure, but civil society,' she complains. Dagen is in her mid40s and grew up in the universe of Dresden's 1980s subversive subculture. She has fond memories of these 'formative' years: 'I was naturally at home in an artist's world, from my childhood on. I was growing into this world and got in touch with many cultural things, as a child already.' Yet, her fond memories of these years are mirrored by the trauma of state repression:

Everything happened under the eyes of the STASI. There were really frightening and threatening situations for me as a child: When the doorbell 
rang and strangers stood in front of the door. They acted as if they'd know you but you have never seen them. They came inside, disappeared with the mother in the study and closed the door.

Even if this memory still has a strong emotional effect on Dagen, she does not want to find out about the realities of that period:

I have not looked into my STASI file. It is bizarre, I know. My husband encouraged me to have a look but what will this change? One would have to re-evaluate one's whole memory and biography and I don't want that.

She wants to keep the fond memories of the intimate artist circles. It is the memory of a free space seemingly untouched by the state, but nevertheless surrounded by its repressive apparatus. Today, this individual memory forms a usable past for Dagen 'giving her strength' in facing the challenges of her present activism. She asserts that all that she learned back then has given her the cultural Bildung (education) necessary to survive in 'today's profit-driven system'. The current debates surrounding PEGIDA, the AfD and refugee policy, she says, these memories come back to her:

Often artists who applied to leave the GDR or criticised the regime disappeared. This was Stalinist purging and I never want to have that again. But I fear today things develop into the same direction. If somebody says something that is not politically correct, he is muted.

The traumatic experience in the late GDR is contrasted with the feeling of community in the artist colony, the nostalgic memory of which is selectively used to interpret the present situation. Today, Dagen sees censorship and a disappearing of 'places of true community'. The account of her own politicization mirrors the development of an apolitical Ostalgie into a negative nostalgia that is politicized for a far-right political struggle: 'I was never a political person. After the end of the GDR we were all just tired of politics. In the GDR politics were everywhere.' Dagen's politicization happened through an activating of the socialist past as a negative nostalgia to frame a far-right opposition to 'today's system'. It is used as a symbolic 
and temporal frame to make sense of the present: 'Today we need spaces like this to be political. If politicians in Berlin don't represent us anymore, we have to make our own politics, here, on the ground. And it has to be politics informed by culture, not merely based on competence. But we need to be confident of our roots, to face the future and save Germany before it disappears.' She is convinced that the decision to 'open the borders' in 2015 was based on German self-hate and will, 'if we don't do anything today', lead to the extinction of Germany. Her activism is informed by a hope in the face of a dystopian future that can still be escaped if 'we act now'.

\section{Relating individual, social and political memories}

Martin was 16 years old when reunification happened. He works as a lecturer in medieval history at the Dresden University and is one of the many local intellectual figures who come regularly to the meetings at Dagen's bookshop. 'I have been ordering my books there since the 1990s,' he says, adding that he enjoys the familiar atmosphere of the bookshop. As he says, he is sympathetic to PEGIDA due to his 'socialization in the east'. Growing up in a pious Catholic environment, his family had always at least passively opposed the GDR state. 'This made life difficult for the family. I was not part of any of the organizations one had to go through to gain the privileges in the GDR.' His childhood in the Erzgebirge. The mountainous region close to Dresden was largely untouched by GDR secularization and is often described as East Germany's bible belt (Lühmann, 2014). For Martin's family, the church was 'extremely important as a counter world to socialism' and 'the repressive regime that went along with it'. Like Dagen's artists' colony, the church was a place of community and freedom from the regime's constant ideological indoctrination, a place where one could speak one's mind freely and find community outside state institutions.

Echoing Dagen, Martin says that this time has made him sensitive towards any form of repression. Today he has many flashbacks regarding the behaviour of the press but also civil society institutions and his university. While he concedes that it is 'of course not the same as the GDR', he still sees parallels: 'If one utters certain views one is being excluded from 
the discourse or even loses one's job,' he says, telling me about a colleague whose contract with the university was not extended because of contentious articles he published. 'And the university tells you what you should do, calls on you to participate in anti-PEGIDA demonstrations, to be open to the world and to condemn hatred. This very much reminds me of the late GDR.'

Martin's account echoes other core group members I interviewed. Many see Dagen's events as analogous to the salons of dissident writers in the 1980s, this time speaking out against the 'muzzling of freedom of speech'. Still others compare the posters supporting diversity and tolerance that the city of Dresden attached at central buildings to socialist propaganda placed on buildings in the GDR. The impact of such historical analogies should not be underestimated (Hochschild 2016, p. 16). Since the end of my fieldwork they have emerged in popular German newspapers ${ }^{5}$ and TV shows ${ }^{6}$ and slogans like 'Vollende die Wende' (complete the revolution) or 'GDR 2.0' were central to the AfD's 2019 election campaigns (Gensing \& Kumpfmüller, 2019).

For most of my informants, the views not to be mentioned are linked to nostalgia for a guilt-free and ethnically white past. As Martin says, 'German memory cannot focus on 12 years of history, this is not normal. Germany has to become more self-confident, more assertive, if it wants to survive.' He says, 'this is especially true with the future we are facing. I believe that we will soon enter an era of tribal wars. All these different cultures that are pouring into Germany. They dissolve the sovereign, the German Volk. This will lead to chaos.' For him Dagen's bookshop is a space where this can be discussed freely and where resistance can be organized: 'Dagen's events and many far-right publications are intellectually highly satisfying. They point to what must change. Even if I am more pessimistic, I believe we can still change things and save what is left of Germany.'

My informants see themselves as intellectuals in the tradition of a non-conformist GDR resistance. It is a prefigurative nostalgia that draws on past resistance and solidarity to enact in their activism the culture-driven, nativist politics they hope for. The coexistence of this utopian nostalgia with a dystopian future shows that hope and anxiety are not necessarily 
antagonistic but complementary. Instead of seeing nostalgia as a monodirectional and fearful past-fixated reaction to change, the activism of such local intellectuals is better understood in terms of 'anxious hope' - a hope driven by dystopian visions of a multicultural future and the belief that it is not too late to act (Gordon, 2018, pp. 543).

\section{Conclusion}

Lengsfeld, Dagen and Martin illustrate Dresden's vibrant far-right intellectual milieu and the ways its members activate individual and social memories of a socialist past for a far-right future. Merging today's dissent with memories of past activism allows such local intellectuals to tell a 'deep story' that, through historical analogy, legitimises individual activism and politicization (Hochschild, 2016, p. 16). Such a prefigurative nostalgia is not a simple glorification or appropriation of the past by the fearful left-behind but the basis for a hopeful far-right activism for an alternative, guiltfree future (Gutmann 2011). Lengsfeld's interaction with her audience's social memories or Martin's and Dagen's framing of activism in terms of individual memories show: the far right can draw on local memory-cultural repertoires of dissent to engineer beneficial cultural opportunity structures and to ensure that nativist framings resonate with concrete cultural contexts (Lubbers \& Coenders, 2017). Drawing on activating forms of negative and positive nostalgias for local and national pasts, these intellectuals simultaneously reassert their role as producers of an exclusive nation (Suny \& Kennedy, 1999) guarding a nativist culture against a multicultural (Sniderman \& Hagendorn, 2007) or 'left-liberal state' (Geyer, 2001, p. 2).

Looking at the different ways far-right ideas resonate locally provides insights not only into far-right micropolitics. It also illustrates the importance of local socio-cultural milieus for a re-elaboration and re-legitimisation of far-right nativism beyond the grassroots level. Since the end of my fieldwork the reference to the socialist past has become a salient feature not only of the East but also the West German far and centre right. Equally, drawing on the past to re-elaborate cultural opportunity structures in the present is a central strategy for the far-right in other European countries and beyond (Caiani et.al. 2012; 
Caramani \& Manucci 2019; Cesari \& Kaya 2019). Analysing how activists in other cities, regions and countries draw on local individual and social memories to make far-right activism locally meaningful may therefore proof fruitful for future research.

\section{Notes}

${ }^{1}$ Other examples are Monika Maron, Uwe Tellkamp, Hans-Joachim Maaz, Michael Beleites, Siegmar Faust, Angelika Barbe (von Hammerstein 2018).

${ }^{2}$ Name given to the time between 1880 and 1914 when the German Empire witnessed a long period of prosperity.

${ }^{3}$ The German term 'pig system' here refers to a corrupt political regime.

${ }^{4}$ For the post-reunification period in Dresden: Ten Dyke (2001).

${ }^{5}$ An early example: Klonovsky (2010). More recently: Broder (2019), Kraus (2019).

${ }^{6}$ East German Journalist Ralf Schuler compared advertisement representing ethnic diversity to GDR propaganda in the popular TV show Hart Aber Fair (2019, min. 42:50-45:00).

\section{References}

Art, D. (2011). Inside the Radical Right. The Development of Anti-Immigrant Parties in Western Europe. Cambridge: CUP.

Art, D. (2018). The AfD and the end of containment in Germany? German Politics \& Society. 36 (2), 76-86.

Assmann, A. (2006a). Der lange Schatten der Vergangenheit: Erinnerungskultur und Geschichtspolitik. Munich: Beck.

Assmann, A. (2006b). Memory, individual and collective. In: Goodin RE and Tilly C (eds) The Oxford Handbook of Contextual Political Analysis. Oxford: OUP, pp. 210-225.

Assmann, A. (2013). Das neue Unbehagen an der Erinnerungskultur Eine Intervention. Munich: Beck.

Bach, J. (2015). Collecting Communism: Private museums of everyday life under Socialism in former East Germany. GPS 33(1/2): 135-145.

Bach, J. (2017). What Remains: Everyday Encounters with the Socialist Past in Germany. New York: Columbia University Press. 
Baumann, S., (2007). A general theory of artistic legitimation: how art worlds are like social movements. Poetics 35, 47-65.

Berdahl, D. (1999). '(N)Ostalgie' for the present: Memory, longing, and East German things. Ethnos 64(2): 192-211.

Berezin, M. (2009). Illiberal Politics in Neoliberal Times: Culture, Security and Populism in the New Europe. New York: CUP.

Betz, H.G. (1994). Radical Right-Wing Populism in Western Europe. Basingstoke: Palgrave.

Betz, H.G., \& Johnson, C. (2016). Against the current-stemming the tide: The nostalgic ideology of the contemporary radical populist right. In: Mudde C (ed.) The Populist Radical Right. London: Routledge, pp. 68-82.

Blee, K. (2002). Inside Organised Racism: Women in the Hate Movement, Berkeley: UCP.

Blee, K. (2007). Ethnographies of the far right, JCE 36(2), 119-28.

Blee, K. \& Creasap, K. (2010). Conservative and Right-Wing Movements. ARS, 36(1), 269-286.

Boggs, C. (1977). Marxism, prefigurative communism and the problem of workers' control. Radical America, 6 (Winter), 99- 122.

Boggs, C. (1993). Intellectuals and the Crisis of Modernity. Albany: SUNY.

Bonikowski, B. (2016). Nationalism in Settled Times, ARS 42, 427-49.

Bonikowski, B. (2017). 'Nationhood as Cultural Repertoire: Collective Identities and Political Attitudes in France and Germany.' In M. Skey \& M. Antonsich (Eds.) Everyday Nationhood: Theorising Culture, Identity and Belonging after Banal Nationalism, (pp. 147-174). London: Palgrave.

Bourdieu, P. (1969). 'Intellectual Field and Creative Project,' SSI 8(2), 889-119.

Boym, S. (2001). The Future of Nostalgia. New York: Basic Books.

Breines, W. (1989). Community and Organization in the New Left 1962-1968: The Great Refusal. New Brunswick: RUP.

Brockmann, S. (1999). Literature and German Unification. Cambridge: CUP. 
Broder, H. (2019). Wie schon Kinder zu Öko-Jakobinern ausgebildet werden, Die Welt Online, 16/6/2019. Available:

https://www.welt.de/debatte/kommentare/plus195263737/Henryk-M-Broder-Fruehuebt-sich-der-junge-Oeko-Jakobiner.html (accessed 17/6/2019).

Caiani, M., Della Porta, D., \& Wagemann, C. (2012). Mobilizing on the Extreme Right: Germany, Italy, and the United States, Oxford: OUP.

Caramani, D., \& Manucci, L. (2019). National past and populism: the reelaboration of fascism and its impact on right-wing populism in Western Europe. WEP.

Castelli Gattinara, P. \& Pirro, A. (2018). The far right as social movement. ES.

Charta 2017 (2017). Available: https://www.openpetition.de/petition/online/charta2017-zu-den-vorkommnissen-auf-der-frankfurter-buchmesse-2017 (accessed 10/7/2019).

Choudry, A. (2015). Learning Activism: The Intellectual Life of Contemporary Social Movements, Toronto: UTP.

Cesari, Chiara De \& Ayhan Kaya (2019). European Memory in Populism. Representations of Self and Other. Accessed 10 4, 2019.

https://taylorfrancis.com/books/9780429454813.

Clarke, D., \& Wölfel, U. (2011). Remembering the German Democratic Republic: Divided Memory in a United Germany. Basingstoke: Palgrave.

Coakley, H. (2004). Mobilizing the Past: Nationalist Images of History, NEP, 10:4, 531-560.

Cohen, Y. (2010). The Germans: Absent Nationality and the Holocaust. Eastbourne: SAP.

Dames, N. (2010). Nostalgia and its disciplines: A response. $M S$ 3(3): 269-275.

Decker, F. (2015). AfD And Pegida: Understanding Germany’s New Populist Right. In: Understanding Pegida in Context, Social Europe Report, (pp. 15-16). Berlin: Friedrich-Ebert-Stiftung.

Decker, O., \& Brähler, E. (2018). Flucht ins Autoritäre: Rechtsextreme Dynamiken in der Mitte der Gesellschaft. Gießen: Psychosozial-Verlag. 
De Vries, C., \& Hoffmann, I. (2018). The power of the past. How nostalgia shapes European public opinion. Eupinions, November 2018. Available: www.bertelsmannstiftung.de/fileadmin/files/BSt/Publikationen/GrauePublikationen/eupinions_Nostal gia.pdf (accessed 26/11/2018).

Die Welt (2018). 'Was wir von Tellkamp hörten, ist uns von Pegida bekannt'. Die Welt Online. Available: https://www.welt.de/kultur/article174525424/Durs-GruenbeinWas-wir-von-Uwe-Tellkamp-hoerten-ist-uns-von-Pegida-bekannt.html (accessed 17/8/2018).

Dilling, M. (2018). Two of the Same Kind? The Rise of the AfD and its Implications for the CDU/CSU, GPS, Issue 126 Vol. 36, No. 1, 84-104.

Dornhof, D. (2001). The Inconsequence of Doubt: Intellectuals and the Discourse on Socialist Unity. In: M. Geyer (ed.) The Power of Intellectuals in Contemporary Germany (pp. 59-87). Chicago: UCP.

Dresden (2019). Europawahl 2019, Amtliches Endergebnis. Presseamt Dresden. Available: http://wahlen.dresden.de/2019/euw/index.html (accessed 10/6/2019).

Druxes, H. (2016a). Introduction. Pegida as a European Far-Right Populist Movement. GPS, 121:34, No. 4, 1-16.

Druxes, H. (2016b). 'Montag ist wieder PEGIDA-Tag!' Pegida’s Community Building and Discursive Strategies. GPS, 121:34, No. 4, 17-33.

Duyvendak, J. (2011). The Politics of Home: Belonging and Nostalgia in Europe and the United States. Basingstoke: Palgrave.

Epstein, B. (1991). Political Protest and Cultural Revolution. Berkeley: UCP.

Ezekiel, R.S. (1995). The Racist Mind: Portraits of American neo-Nazis and Klansmen, New York: Penguin Books.

Frei, N. (1996). Vergangenheitspolitik : die Anfänge der Bundesrepublik und die NSVergangenheit. Munich: Beck.

Fulbrook, M. (1999). German National Identity after the Holocaust. Cambridge: Polity Press. 
Geiger, T. (1949). Aufgaben und Stellung der Intelligenz in der Gesellschaft. Stuttgart: Enke.

Gensing, P. \& Kumpfmüller, K. (2019). Leben wir in einer "DDR 2.0"? Tagesschau Online, 2/8/2019. Accessible: https://www.tagesschau.de/faktenfinder/ddrvergleich-wende-101 origin-a2ba8b9e-b73a-423c-bce3-08d0cb3b627c.html (accessed 17/10/2019).

Geyer, M. (2001). Introduction. The Power of Intellectuals in Contemporary Germany. In: M. Geyer (ed.) The Power of Intellectuals in Contemporary Germany (pp. 126). Chicago: University of Chicago Press.

Giesen, B. (1998). Intellectuals and the Nation. Collective Identity in a German Axial Age, Cambridge: CUP.

Glaeser, A. (2000). Divided in Unity: Identity, Germany, and the Berlin Police. Chicago: UCP.

Graf, A. (2001). Media Publics in the GDR: Reunification and the Transformation of the Media, 1989-1991. In M. Geyer (ed.) The Power of Intellectuals in Contemporary Germany (pp. 249-275). Chicago: UCP.

Goodwin, M. \& Milazzo, C. (2005). UKIP. Inside the Campaign to Redraw the Map of British Politics. Oxford: OUP.

Göpffarth, J. (2017). The rise of Germany’s AfD: From ordoliberalism to new right nationalism and into the Bundestag? In LSE EUROPP Blog. Available: http://blogs.lse.ac.uk/europpblog/2017/06/27/the-rise-of-germanys-afd/ (accessed 22/7/2018).

Göpffarth, J. (2018). Between the 'street' and the 'salon,' the local and the national: Mediating intelligentsia and the German New Right in Dresden. Europe Now Journal 21, October 2018. Available: www.europenowjournal.org/2018/10/01/between-the-street-and-the-salon-thelocal-and-the-national-mediating-intelligentsia-and-the-german-new-right-indresden/ (accessed 28/10/2018).

Göpffarth, J. (2020). Rethinking the German nation as German Dasein: Intellectuals and Heidegger's philosophy in contemporary German New Right nationalism. JPI 20 (forthcoming). 
Gordon, U. (2018). Prefigurative politics between ethical practice and absent promise. PS 66(2): 521-537.

Gutman, Y. (2011). Transcultural Memory in Conflict: Israeli-Palestinian Truth and Reconciliation. Parallax 17 (4): 61-74.

Hart Aber Fair (2019). In Europa, in Deutschland: Wie viel Populismus verträgt die Politik?, 13/5/2019. Accessible: https://www1.wdr.de/daserste/hartaberfair/videos/video-in-europa-in-deutschlandwie-viel-populismus-vertraegt-die-politik--102.html (accessed 10/7/2019).

Hansen, M., \& Olsen, J. (2019). Flesh of the Same Flesh: A Study of Voters for the Alternative for Germany (AfD) in the 2017 Federal Election. GP 28(1), 1-19.

Heilbrunn, J. (1996). Germany’s New Right. FA 75(6), 80-98.

Herf, J. (1997). Divided Memory: The Nazi Past in the Two Germanys. Cambridge: HUP.

Hochschild, A.R. (2016). Strangers in Their Own Land: Anger and Mourning on the American Right. New York: The New Press.

Hollands, R., \& Vail, J. (2012). The art of social movement: Cultural opportunity, mobilisation, and framing in the early formation of the Amber Collective, Poetics $40,22-43$.

Hoye, M. \& Nienass, B. (2014). Authority without Foundations. Arendt and the Paradox of Postwar German Memory Politics, The Review of Politics 76, 415-437.

Jäger, W., \& Villinger, I. (1997). Die Intellektuellen und die deutsche Einheit, Freiburg: Rombach.

Jones, F. L., \& Smith, P. (2001). Diversity and commonality in national identities: An exploratory analysis of cross-national patterns. JS, 37(1), 45-63.

Kaiser, P., \& Petzhold, C. (1997). Boheme und Diktatur in der DDR. Berlin: Fannei \& Walz.

Kattago, S. (2001). Ambiguous Memory: The Nazi Past and German National Identity. Westport: Praeger.

Kenny, M. (2017). Back to the populist future? Understanding nostalgia in contemporary ideological discourse. $J P_{25} 22(3), 256-273$. 
Klandermans, B., \& Mayer, N. (2005). Extreme Right Activists in Europe: Through the Magnifying Glass, London: Routledge.

Klonovsky, M. (2010). Auf dem Weg in die DDR 2.0, Focus Online, 1/10/2010. Available: https://www.focus.de/politik/deutschland/20-jahre-wende/tid20035/kommentar-auf-dem-weg-in-die-ddr-2-0_aid_557918.html (accessed 14/6/2019).

Koopmans, R. \& Braun, R. (2014). Watch the Crowd: Bystander Responses, TrickleDown Politics, and Xenophobic Mobilization, CPS, 47(4), 631-658.

Koopmans, R. (2016). Statistical and Perceived Diversity and Their Impacts on Neighborhood Social Cohesion in Germany, France and the Netherlands, SIR, February 2016, Volume 125, Issue 3, 125:853-883.

Kraus, J. (2019). DDR 2.0 - Wir sind ein Volk von Flüsterern geworden. Tichy's Einblick, 23/5/2019. Available: https://www.tichyseinblick.de/daili-es-sentials/ddr2-0-wir-sind-ein-volk-von-fluesterern-geworden/ (accessed 14/6/2019).

Kukula, R., \& Helas, V. (2007). Ballhäuser in Dresden. Dresden: Sandstein. Lahusen, C., \& Bleckmann, L. (2015). 'Beyond the Ballot Box: Changing Patterns of Political Protest Participation in Germany (1974-2008)', GP, 24(3), 402-26.

Langenbacher, E. (2010a). Collective memory as a factor in political culture and international relations. In: Langenbacher E and Shain Y (eds) Power and the Past: Collective Memory and International Relations (pp. 13-49). Washington: GUP.

Langenbacher, E. (2010b). The mastered past? Collective memory trends in Germany since unification. GPS 28(1), 42-68.

Langenbacher, E. (2014). Does collective memory still influence German foreign policy? The Brown Journal of World Affairs 20(2), 55-71.

Lengsfeld, V. (2014). 1989 - Tagebuch der Friedlichen Revolution: 1. Januar bis 31. Dezember. Jena: TvR Medienverlag.

Lengsfeld, V. (2018a). Erklärung 2018. Available: www.erklaerung2018.de/ (accessed 24/5/2018). 
Lengsfeld, V. (2018b). '1989. Tagebuch der Friedlichen Revolution'. Book reading and discussion with Susanne Dagen, Lindengarten Dresden, April 19, 2018 (https://www.kulturhaus-loschwitz.de/weiteres.html), fieldnote diary 4.

Leo, A. (2004). Nicht Vereint: Studien zum Geschichtsbewusstsein Ost- und Westdeutscher. In: Behrens H and Wagner A (eds) Deutsche Teilung, Repression und Alltagsleben: Erinnerungsorte der DDR-Geschichte. Leipzig: Forum Verlag, pp. 58-68.

Ley, M., \& Lichtmesz, M. (2018). Nationalmasochismus. Schnellroda: Antaios.

Lubbers, M. (2008). Regarding the Dutch 'Nee' to the European Constitution. A test of the identity, utilitarian, and political approaches to voting 'no'. EUP 9(1), 59-86.

Lubbers, M., \& Coenders, M. (2017). 'Nationalistic Attitudes and Voting for the Radical Right in Europe', EUP 18(1), 98-118.

Lühmann, M. (2014). Der sächsische Biblebelt. In: Blog des Göttinger Instituts für Demokratieforschung, 29 August. Available: www.demokratiegoettingen.de/blog/saechsische-biblebelt (accessed 29/11/2018).

Maeckelbergh, M. (2011). Doing is believing: Prefiguration as strategic practice in the Alterglobalization Movement. SMS 10(1), 1-20.

Maier, C. (1988). The Unmasterable Past: History, Holocaust, and German National Identity. Cambridge: Malthouse Press.

Mense, T., Schubert, F., \& Wiedemann, G. (2016). Von »besorgten Bürgern« zu Widerstandskämpfern? - Pegida und die Neue Rechte (2016). In Die enthemmte Mitte : autoritäre und rechtsextreme Einstellung in Deutschland: die Leipziger 'Mitte'-Studie (pp. 179-200). Gießen : Psychosozial-Verlag.

Morina, C. (2011). Legacies of Stalingrad: Remembering the Eastern Front in Germany Since 1945. Cambridge: CUP.

Moses, A. (2007). German Intellectuals and the Nazi Past. New York: CUP.

Mudde, C. (2007). Populist Radical Right Parties in Europe, Cambridge: CUP.

Müller, J. (1999). From national identity to national interest: The rise (and fall) of Germany’s new right. GP 8(3): 1-20.

Olick, J. (2003). The guilt of nations? EIA $\mathbf{2} 7(2):$ 109-117. 
Olick, J. (2008). 'Collective memory': A memoir and prospect. MS 1(1): $23-29$.

Olsen, J. (2015). Tailoring Truth: Politicizing the Past and Negotiating Memory in East Germany, 1945-1990. New York: Berghahn Books.

Ost, D. (2005). The Defeat of Solidarity: Anger and Politics in Postcommunist Europe. London: Cornell University Press.

Patton, D. (2017). Monday, Monday: Eastern Protest Movements and German Party Politics since 1989, GP, 26:4, 480-497.

Palmowski, J. (2009). Inventing a Socialist Nation: Heimat and the Politics of Everyday Life in the GDR, 1945-1990. Cambridge: CUP.

Peitsch, H. \& Sayner, J. (2015). Tendentiousness and topicality: Buchenwald and antifascism as sites of GDR memory. GPS 33(1/2): 100-118.

Pilkington, H. (2016). Loud and proud. Passion and politics in the English Defence League. Manchester: MUP.

Probst, L. (2003). Founding myths in Europe and the role of the Holocaust. NGC 90: $45-58$.

Reed, T. (2005). The Art of Protest: Culture and Activism from the Civil Rights Movement to the Streets of Seattle. Minneapolis: UMP.

Reinhard, D. (2018). Weltbürger trifft Sorgenbürger. Die Zeit Online. Available: https://www.zeit.de/kultur/literatur/2018-03/dresden-uwe-tellkamp-durs-gruenbeinafd-pegida (accessed 17/08/2018).

Rohrmoser, G. (1990). Ideologie-Zerfall: Nachruf auf die geistige Wende (Gegenwart und Zeitgeschichte). Krefeld: Sinus.

Roth, M. (1991). Dying of the past: Medical studies of nostalgia in nineteenth-century France. History and Memory 3(1): 5-29.

Rothberg, M. (2009). Multidirectional Memory: Remembering the Holocaust in the Age of Decolonization. Stanford: SUP.

Salzborn, S. (2016). Renaissance of the New Right in Germany?: A discussion of New Right elements in German right-wing extremism today. GPS 34(2): 36-63.

Scheepers, P., Gijsberts, M., Hagendoorn, L. (eds) (2004). Nationalism and Exclusion of Migrants. Cross-National Comparise8s. Aldershot: Ashgate. 
Scheepers, P, Lubbers, M., Werts, H. (2013). Euro-scepticism and radical right-wing voting in Europe, 2002-2008: Social cleavages, socio-political attitudes and contextual characteristics determining voting for the radical right, EUP, 14(2), 183205.

Schwilk, H. (1995). Die selbstbewusste Nation: Anschwellender Bocksgesang und weitere Beiträge zu einer deutschen Debatte. Frankfurt: Ullstein.

Shulman, S. (2002). Challenging the civic/ethnic and West/East dichotomies in the study of nationalism. CPS, 35(5), 554-585.

Sieferle, R.P. (2017). Finis Germania. Kaplaken 5. Schnellroda: Antaios.

Sierp, A. (2009). Nostalgia for times past: On the uses and abuses of the ostalgie phenomenon in Eastern Germany. CES 2: 47-60.

Simpson, P. A. (2016). Mobilizing Meanings. Translocal Identities of the Far Right Web. GPS, 121:34, No. 4, 34-53.

Sitrin, M. (2006). Horizontalism: Voices of Popular Power in Argentina. Oakland: AK Press.

Smith, A. (1996). LSE Centennial Lecture: The Resurgence of Nationalism? Myth and Memory in the Renewal of Nations, BJS, 47:4, 575-598.

Sniderman, P. M., \& Hagendoorn, L. (2007). Multiculturalism And Its Discontents in the Netherlands. When Ways of Life Collide. Oxford: PUP.

Snow, D. A., \& Benford, R. D. (1988). Ideology, frame resonance, and participant mobilization. International Social Movement Research Vol. 1, 197-217.

Steenvoorden, E. \& Harteveld, E. (2018). The appeal of nostalgia: The influence of societal pessimism on support for populist radical right parties. WEP 41(1): 28-52.

Stewart, K. (1988). Nostalgia—A polemic. Cultural Anthropology 3(3): 227-241.

Suny, R., \& Kennedy, M. D. (1999). Intellectuals and the Articulation of the Nation. Ann Arbor: UMP.

Susen S. (2017). Reflections on Patrick Baert's The Existentialist Moment: The Rise of Sartre as a Public Intellectual. In P. Baert \& S. Susen (eds), The Sociology of Intellectuals: After 'The Existentialist Moment' (pp. 1-122). Cham: Palgrave. 
Ten Dyke, E.A. (2001). Dresden: Paradoxes of Memory in History. New York: Routledge.

Toscano, E. (2019). Researching Far Right Movements Ethics, Methodologies, and Qualitative Inquiries. London: Routledge.

Virchow, F. (2017). Post-Fascist Right-Wing Social Movements. In S. Berger and H. Nehring (eds), The History of Social Movements in Global Perspective (pp. 619646). London: Palgrave.

Veugelers, J. \& Menard, G. (2018). The Non-Party Sector of the Radical Right. In J. Rydgren (ed.), The Oxford Handbook of the Radical Right (pp. 285-304). Oxford: OUP.

Von Hammerstein, K. (2018). Warum ehemalige Bürgerrechtler sich jetzt bei der AfD engagieren. Spiegel Online, 7 January. Available: www.spiegel.de/spiegel/warumddr-buergerrechtler-sich-bei-der-afd-engagieren-a-1186288.html (accessed 4/9/ 2018).

Vorländer, H., Herold, M. \& Schäller, S. (2015). Wer geht zu PEGIDA und warum? Eine empirische Untersuchung von PEGIDA-Demonstranten in Dresden. Schriften zur Verfassungs- und Demokratieforschung, 1/2015, Dresden: Zentrum für Verfassungs- und Demokratieforschung.

Weisskircher, M., \& Berntzen, L. E. (2018). Remaining on the Streets. Anti-Islamic PEGIDA Mobilization and its Relationship to Far-right Party Politics. In M. Caiani \& O. Císar, Radical Right Movement Parties in Europe (pp. 114-130), London: Routledge.

Whitehead, H. (2010). The agency of yearning on the Northwest Coast of Canada: Franz Boas, George Hunt and the salvage of autochthonous culture. MS 3(3): 215223.

Winter, J. (2000). The generation of memory: Reflections on the 'memory boom' in contemporary historical studies. Bulletin of the German Historical Institute 27(Fall): 69-92.

Wittlinger, R. (2008). The Merkel Government's politics of the past. GPS 26(4): 9-27. 
Wüstenberg, J. (2017). Civil Society and Memory in Postwar Germany. Cambridge: CUP.

Wüstenberg, J., \& Art, D. (2008). Using the past in the Nazi successor states from 1945 to the present. The Annals, 617(1), 72-87. 